\title{
Export Effect of China's Outward FDI: Provincial Panel Data Analysis
}

\author{
Xiaohui Wang ${ }^{1}$ \\ ${ }^{1}$ School of Economics and Management, LeShan Normal University, LeShan, Sichuan Province, China \\ Correspondence: Xiaohui Wang, School of Economics and Management, LeShan Normal University, No.402, \\ Unit2, JinLin, ManTingFang, No.776, Xiaoba Road, LeShan City, Sichuan Province, China.
}

Received: May 25, 2017

doi:10.5539/ibr.v10n7p148

\author{
Accepted: June 5, 2017 \\ Online Published: June 19, 2017 \\ URL: https://doi.org/10.5539/ibr.v10n7p148
}

\begin{abstract}
China's direct investment overseas reaches US\$170.11 billion and is US\$44 billion more than the actual use of foreign investment, which makes China a net capital exporter. Large scale of Outward Foreign Direct Investment also has a great influence on the export. This article made an estimation on the export effect of Outward Foreign Direct Investment through fixed effect model and Generalized Method of Moment based on the provincial panel data from 2004 to 2014. The result shows Outward Foreign Direct Investment has a positive effect on export whether in the whole country or in different districts, every $1 \%$ increase of Outward Foreign Direct Investment will lead to about $0.1 \%$ rising in export, and moreover positive effect of Outward Foreign Direct Investment in the middle and western districts is stronger than that in the eastern district.
\end{abstract}

Keywords: export effect, Outward Foreign Direct Investment (OFDI), provincial panel data, system Generalized Method of Moment (GMM)

\section{Introduction}

According to the statistics from China's ministry of commerce and state administration of foreign exchange, in 2016, the Chinese investors made direct investment overseas in 7,961 enterprises of 164 countries and regions. The direct investment overseas amounted to RMB 1.12992 trillion, going up 53.7\% year on year (equivalent to US $\$ 170.11$ billion, up $44.1 \%$ year on year). The direct investment overseas is US\$44 billion more than the actual use of foreign investment which reached US $\$ 126$ billion in 2016, which means that China has become a net capital exporter. Under the influence of the strategy of Belt and Road, China will expand the foreign investment and encourage transferring competitive industries and excessive capacity to the countries along the Belt and Road, building array of interconnection projects and increasing the investment on manufacturing, service and other industries in the countries along the Belt and Road. Meanwhile, China was a great country in absorbing the foreign investment capital, second to USA. Why does China need large scale of outer foreign direct investment, and what influence will be brought by the large scale of outer foreign direct investment on export which is a major driver of Chinese economic growth? Will it promote export or replace export? Study on this problem not only contributes to the economy theory, but also to the practice.

There are two ways for a country to enter into the international market: export and Outward Foreign Direct Investment (hereinafter referred to as OFDI). Export means products are made in native country and sold to the international market, which will be affected by the tariff, non-tariff wall and transportation cost. While OFDI means the native company sets up factory in the foreign countries and sell its products there or to a third country. Internationalization of production and block factorization of value chain merge with the elimination of tariff wall and decrease of transportation and communication cost, and thus industry becomes multinationalization and its value chains are subdivided into many countries. In this way, Company can complete all production procedure in the district with highest efficiency and lowest cost, and thus wins the competitive advantages. When OFDI is implemented in host country, will it replace home country's export to the host country or be complementary to the export in home country? There are some different conclusions in theoretical study and practical study. OFDI can replace as well as complement the export of motherland in theoretical study, while it is complementary to the export in the practical study.

The article tries to analyze the influence of OFDI to export in China based on the provincial panel data of 2004 to 2014 through the ways of fixed effects and GMM estimation, and further propose suggestion for the development of OFDI in China. 


\section{Literature Review}

Whether OFDI promotes or replaces export is a hot topic in international economy field all the time, and no definite answer was made to it in economy theory. On the hypothesis of new classic Heckscher-Ohlin-Samuelson theory, Mundell (1957) studied on the relationship between OFDI and export. New classic theory supposed that the flow of OFDI depends on the difference of factor price and factor endowment among countries. Difference between factor price and factor endowment shrinks with the international flow of factor. Therefore Mundell assumed that capital flow pushed by OFDI replaces export. Internalization theory (Williamson, 1975; Markusen \& Venables, 1998) assumed that OFDI would replace export when OLI-conditions proposed by Dunning (1977) is valid and a large amount of external trade cost(such as the cost of export and permission) exists. Besides, Brainard (1992) stated fixed cost, transportation cost and "proximity-concentration trade-off" caused by trade barrier are the explanations for replacement relationship between OFDI and trade.

There are two types of FDI, one is horizontal FDI(international company sets up subsidiary corporations in many countries for transportation cost and more close to the consumers) and another is vertical FDI(international corporation puts it's different producing links in different countries according to the cost advantages). Horizontal FDI model shows FDI has a negative effect on export, and thus forms a replacement relationship. Markusen (1984) found the replacement relationship between horizontal FDI and export. So whether international corporation should set up a subsidiary institution or export depends on the one hand on the trade cost (tariff), and on the other hand on the cost of setting up a factory close to the consumer. At last, the model speculate the negative relation between technology difference and horizontal FDI when horizontal FDI appears in the countries where factor endowment, income and technology are close to each other. Markusen \& Venables(1998) set up a model and discover that when different factor endowment and technique in different countries become similar, FDI and trade forms replacement relationship.

Other theory presumes that OFDI and trade may be complementary to each other. The reason of the complementary relation between vertical FDI and export can be attributed to the increase of input product export from motherland to host country promoted by the investment of manufacturer (Svensson, 1966). Helpman (1984) pointed out in his model that vertical FDI and export are complementary and foreign subsidiary corporation export the final products to its parent firm, while parent firm exported semi-finished products to foreign subsidiary company. The model also shows that vertical FDI tends to take place between developed country and developing country. For example, producing in other countries may increase the total demands of entire product line (Lipsey \& Weiss, 1984).

In spite of different empirical study method, most researchers predict that a positive relationship exist between OFDI and export. According to the data hierarchy, empirical literature can be classified into such types as national level study, industry-level study, corporation-level study and product-level study.

Study from national level indicates OFDI and export are complementary. Swedenborg (1979) found that OFDI's effect on the parent exports is weak, while new exports(such as intermediate goods) are incurred. This result was confirmed in his study of 1982 which came to the conclusion that each dollar of local sales substitutes only 2 cents of exports but "creates" 12 cents of new exports, so there is a net positive complementary effect of 10 cents. Pfaffermayr(1994,1996) reached the conclusion of obvious bilateral positive effect through Granger causality test when he was studying the relationship between FDI and export of Austria. In addition, Eaton \& Tamura (1994) also got a complementary conclusion of the relationship between ODFI and export through analysis. However, Clausing (2000) discovered OFDI had a strong positive impact on export through his study on the business state of American international corporations in 29 host countries from 1977 to 1994. When multinational activities and intra-firm trade were taken into consideration, this positive effect are more obvious. Egger, P.(2001) found that exports and stocks of outward FDI are found to be substitutes with respect to changes in transport costs and complements with respect to most of the other determinants through his study. Bajo-Rubio, O., \& Montero-Muñoz, M. (2001) found the existence of a relationship of complementarity between both variables, with Granger causality running in the short run from outward FDI to exports.

The result of empirical study of the industry-level is mixed. Lipsey \& Weiss (1981) discovered American OFDI in 40 countries in 1970 has a positive impact on export and one dollar OFDI can increase 2 to 78 cents' export in the correspondent market. Through the study on American 27 related markets in the product level, Brainard (1997) found that when the per capital income in the partner country is close to that of America, OFDI tends to replace export. While at the same time, Blonigen (2001) discovered if Japan manufactures car components in America, OFDI will replace Japanese's export of car components to America. The further study also shows that a complementary relation exists between Japan's manufacturing cars in America and its exporting car components 
to America. Marchant et al. (2002) also identified the complementary relationship between OFDI and export through the research on the investment of American food industry in Free Trade Area of America. Turkan's study (2006) shows that America's OFDI and its intermediate goods are complementary, however, OFDI has a little bit of negative effect on the export of final products.

On the corporation level, Lipsey \& Weiss (1984) studied the relationship between America's manufacturing the intermediate products in the host country and its export to the host country in 1970, and found a strong complementary relation did exist between the two parts, for increasing one dollar's investment in host country might lead to an increase of 9 to 25 cents' export of the mother country.

With the development of Chinese OFDI, more attention are paid to the study of OFDI's effect on export, but studies in China are empirical in the macro level. Ruqing Zhang (2005) discovered import and export have a great influence on OFDI, while the impact of OFDI on import and export is not significant through a study on Chinese annual OFDI and the data of import and export from 1982 to 2002 by applying the cointegration theory, error correction model and Granger causality test to the study. Through an empirical study on the panel data of China's investment and trade in 50 countries or districts from 2000 to 2006 via gravity model, Benwu Xiang (2009) found that OFDI has an apparent positive influence on Chinese export to the host country, but the effect is not obvious in a short term. Jie Xie and Renyu Liu (2011) also discovered China's OFDI and trade are complementary through a study on the trade effect of China's OFDI. Chunping Zhang (2012) also discovered that effect of China's OFDI on trade is obvious positive. Yuyu Chen (2012), Yuehong Sui and Zhenhua Zhao (2012) made an empirical study on the impact of China's OFDI on trade structure based on time series and panel data model, and also pointed out that OFDI affected the trade structure greatly. Guanhong Jiang (2014) found that OFDI of Chinese corporation promotes export, and OFDI not only deepens the intensive margin of export, but also expands its extensive margin through checking trade effect of 1498 corporations' OFDI from 2005 to 2007 through data matching method and difference-in-differences Estimation. Shen Wang(2014) proved that the trade effect of China's OFDI has national differences through an empirical study on the panel data from 2003 to 2011 with the extended gravity model.

From the above analysis, researches outside China on OFDI focused on those developed countries in Europe, America, Japan and so on, while few are made on the relation between Chinese OFDI and trade. What's more, literature in China discussed the trade effect of Chinese OFDI from the perspective of difference of nationality and district, seldom from different regions in the country itself. In fact, There is a great difference in the level of economic development and natural endowment in different regions in China, and thus OFDI in different regions will lead to different export effect. Therefore, the article will analyze the export effect of Chinese OFDI from the perspective of different regions in China and enrich the study on this subject.

\section{Research Design}

\subsection{Model Specification}

Panel data can overcome the problem of insufficient of sample, and can analysis heterogeneity between individuals through the combination of time series data and cross section data. Therefore, following Chunping Zhang. (2012), a panal data model of analysis of OFDI's effect on export is employed in this article as follows:

$\ln E X P_{i t}=\beta_{0}+\beta_{1} \ln E X P_{i(t-1)}+\beta_{2} \ln O F D I_{i t}+\varepsilon_{i t}$

Where $E X P_{i t}$ denotes the value of merchandise export in $i$ district of China in $t$ year, $E X P_{i(t-1)}$ denotes the value of merchandise export in $i$ district of China in $t-1$ year. The first-lagged merchandise export can be treated as the proxy variable of parts of omitted variables, and it can reflect the self inertia and lasting influence of merchandise export. The first-lagged merchandise export also makes the model the typical dynamic panel model. $O F D I_{i t}$ denotes the outer foreign direct investment stock of $i$ district of China in $t$ year, $\varepsilon_{i t}$ denotes the random disturbance term. This model is a logarithmic model, the parameters are the elastic coefficients of the explanatory variables to the dependent variables, and the logarithmic model can keep the square deviation from being too large.

\subsection{Data and Descriptive Statistics}

The data of the article is panel data of value of export and outer foreign direct investment stock of 31 provinces and autonomous regions of China from 2004 to 2014. Data of value of export came from the gross export of source of supply in the statistic yearbook of National Bureau of Statistics of China. Data of OFDI stock came from Statistical Bulletin of China's Outward Foreign Direct Investment. The main description of the variable is as table 1 . 
Table 1. Variable descriptive statistics

\begin{tabular}{|c|c|c|c|c|c|c|}
\hline variable & & Mean & Std.Dev. & Min & Max & Observations \\
\hline \multirow{3}{*}{ logexport } & overall & 9.308675 & 1.771658 & 4.675312 & 13.52155 & $\mathrm{~N}=341$ \\
\hline & between & & 1.712533 & 5.846582 & 12.94828 & $\mathrm{n}=31$ \\
\hline & within & & .5406099 & 7.817823 & 11.1816 & $\mathrm{~T}=11$ \\
\hline \multirow{3}{*}{ Logofdi } & overall & 6.048284 & 2.288734 & 0 & 10.80931 & $\mathrm{~N}=341$ \\
\hline & between & & 1.762718 & 1.071211 & 9.252968 & $\mathrm{n}=31$ \\
\hline & within & & 1.490811 & 1.536981 & 9.049123 & $\mathrm{~T}=11$ \\
\hline
\end{tabular}

This article draw a scatter diagram of logarithm of export and logarithm of OFDI. According to figure 1, an apparent positive relation between OFDI and export shows OFDI may have a positive effect on export. But the relationship between china's OFDI and export needs further verification.

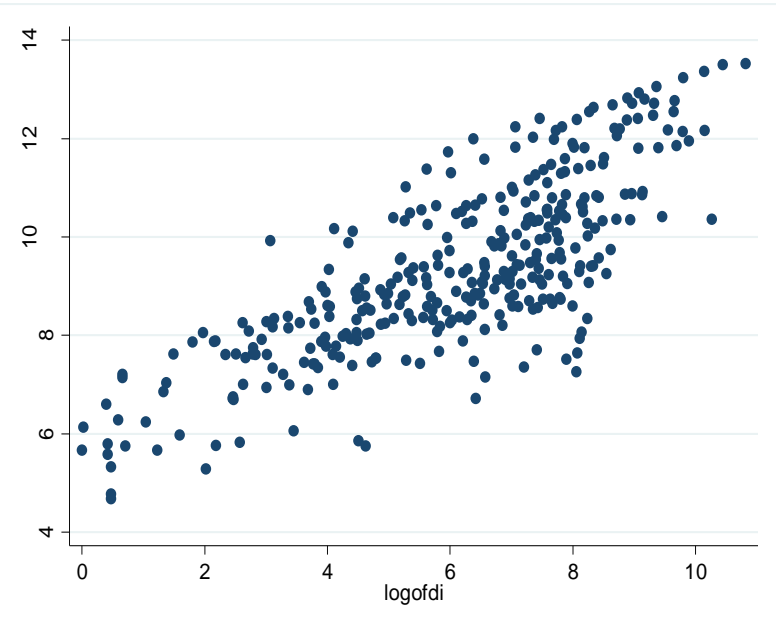

Figure 1. Scatter diagram of china's export and Outer Foreign Direct Investment

\section{Empirical Analysis}

\subsection{Research Method}

This article tries to study the export effect of OFDI in China from 2004-2014 based on panel data model through STATA soft. Spurious regression might be caused by the non-stationary of the panel data, so LLC method and Fisher-PP method will be adopted to test the stationary of panel data. If the panel data is stationary, the model can be estimated directly; if the panel data is non-stationary, co-integration test and adjustment of the model should be made before estimation of model. After the test of stationary, the random effect and fixed effect will be estimated, and Hausman test will be made to judge which one is appropriate for the this article.

Owing to the causality between OFDI and export, deviation may be occurred when OLS model was directly adopted in the estimation. In order to solve the endogenous problem, a first-lagged of merchandise export is added to the explanatory variables as the proxy variable of parts of omitted variables, which is able to reflect the self inertia and makes the model the typical dynamic panel model. Therefore, this article adopts the way of system GMM to make the regression analysis for the advantage in GMM which allows heteroscedasticity and serial correlation in the random error. The results of auto correlation test of first order difference and second order difference will be respectively attached to the latter part in the article.

In order to analyze the difference of the export effect of OFDI in different regions of China, this article divided the 31 regions of the panel data into three main parts, eastern district, middle district and western district, on which a respective estimation will be made and results will be further compared.

\subsection{Stationary Test}

Panel data may cause false regression because of non-stationary of the data, so this article firstly tests the stationary of the panel data. If panel data is non-stationary, data needs to be cointegrated, or the model needs to be adjusted before estimation. The main ways of stationary test of panel data are LLC(Levin-Lin-Chu Test) and Fisher-PP. This article proceeds the stationary test and results of test of all variables are in the table 2 . According to table 2 , all variables are stationary because they have no unit root. 
Table 2. Results of stationary test of all variables

\begin{tabular}{llll}
\hline variable & & logexport & logofdi \\
\hline \multirow{2}{*}{ LLC } & statistic & -6.0616 & -6.7429 \\
& P value & 0.0000 & 0.0000 \\
\multirow{2}{*}{ Fisher-PP } & statistic & 97.5798 & 121.2224 \\
& P value & 0.0026 & 0.0000 \\
\hline
\end{tabular}

\subsection{Regression Analysis}

This article first estimates the model by the ways of pooled OLS, fixed effect and random effect without first-lagged explained variable. Fixed effect method is more suitable because of the result of F test, BPLM test and hausman test. Later the model was estimated by the ways of pooled OLS, fixed effect and system GMM with first-lagged explained variable. The result of regression is as table 3.

Table 3. Regression result of the model (explained variable: logexport)

\begin{tabular}{llllll}
\hline $\begin{array}{l}\text { explaining } \\
\text { variables }\end{array}$ & $\begin{array}{l}\text { Regress 1 } \\
\text { POLS }\end{array}$ & $\begin{array}{l}\text { Regress 2 } \\
\text { FE+Robust }\end{array}$ & $\begin{array}{l}\text { Regress 3 } \\
\text { POLS }\end{array}$ & $\begin{array}{l}\text { Regress 4 } \\
\text { FE+Robust }\end{array}$ & $\begin{array}{l}\text { Regress 5 } \\
\text { sysGMM }\end{array}$ \\
\hline L.logexport & & & $0.995^{* * *}$ & $0.731^{* * *}$ & $0.657^{* * *}$ \\
& & & $(0.00811)$ & $(0.0729)$ & $(0.0870)$ \\
logofdi & $0.609 * * *$ & $0.289^{* * *}$ & -0.00758 & $0.0596^{* * *}$ & $0.0953^{* * *}$ \\
& $(0.0579)$ & $(0.0285)$ & $(0.00865)$ & $(0.0160)$ & $(0.0330)$ \\
Constant & $5.627 * * *$ & $7.560^{* * *}$ & $0.242^{* * *}$ & $2.265^{* * *}$ & $2.714^{* * *}$ \\
AR (1) & $(0.292)$ & $(0.173)$ & $(0.0789)$ & $(0.585)$ & $(0.672)$ \\
AR (2) & & & & & 0.0045 \\
R-squared & 0.618 & 0.636 & 0.982 & 0.810 & 0.9196 \\
N & 341 & 341 & 310 & 310 & 310 \\
region & & 31 & & 31 & 31 \\
\hline
\end{tabular}

Robust standard errors in parentheses

$* * * \mathrm{p}<0.01, * * \mathrm{p}<0.05, * \mathrm{p}<0.1$

From table 3 , in the results of regress 1 , regress 2, regress 4 and regress 5 all coefficients are positive and significant and the coefficient of determination is much larger which mean China's OFDI has an apparent positive effect on export. The determination Coefficients of regression 3 and regression 4 are much lager than that of regression 1 and regression 2, and the coefficients of OFDI are much smaller. That means the model is more suitable and close to practice when first-lagged explained variable is added to the model. The system GMM method adopted in regression 5 is the most suitable estimating way for the dynamic panel model because of taking account of heteroscedasticity and serial correlation in the random error. Besides, result of regression 5 indicates that the first order auto-correlation exists but second order of auto-correlation doesn't exist in the difference of disturbing term, so the original hypothesis of no auto-correlation of disturbing term is accepted. In regression 5 the coefficient of lagged export is 0.657 , which means $1 \%$ increase in export will lead to $0.657 \%$ increase in export of next year and thus China's export has large inertia and lasting influence. Coefficient of OFDI is 0.0953 , which explains that $1 \%$ rise of OFDI causes the rise of $0.0953 \%$ in the export.

Table 4. Regression result of the model (explained variable: logexport)

\begin{tabular}{llll}
\hline \multirow{2}{*}{ explaining variables } & Regress 1(eastern) & Regress 2(middle) & Regress 3(western) \\
& POLS & FE+Robust & $0.697^{* * *}$ \\
L.logexport & $0.653^{* * *}$ & $0.489^{* * *}$ & $(0.0727)$ \\
& $(0.0173)$ & $(0.0531)$ & $0.127^{* * *}$ \\
logofdi & $0.0547^{* * *}$ & $0.165^{* * *}$ & $(0.0312)$ \\
& $(0.0135)$ & $(0.0242)$ & $1.900^{* * *}$ \\
Constant & $3.431^{* * *}$ & $3.704^{* * *}$ & $(0.410)$ \\
AR (1) & $(0.131)$ & $(0.347)$ & 0.0352 \\
AR (2) & 0.0052 & 0.1253 & 0.6294 \\
N & 0.0129 & 0.1425 & 110 \\
region & 120 & 80 & 11 \\
\hline
\end{tabular}

Robust standard errors in parentheses

$* * * \mathrm{p}<0.01, * * \mathrm{p}<0.05, * \mathrm{p}<0.1$

Due to the differences in the economic development, technology level, factor endowment and level of opening up, OFDI has different influence on export in different areas. Therefore, this article divides 31 districts of the panel data into 3 main part as eastern district, middle district and western district, and then performs estimations 
on them by system GMM method respectively. The result of regression is as table 4 . According to table 4, OFDI in Chinese eastern district, middle district and western district both has an apparent effect on export, while the effect is imbalanced. OFDI in middle and western districts has a powerful positive effect on export, while that effect of OFDI in eastern district on export is weaker.

\section{Conclusion and Suggestion}

\subsection{Research Conclusion}

Through the estimations of fixed effect model and GMM made on Chinese OFDI in 31 regions and in different districts, such conclusion is reached: positive effect of OFDI on export is significant. When first-lagged explained variable is taken into consideration in GMM estimation, $1 \%$ increase of OFDI will lead to $0.0953 \%$ rising in export. In terms of the three districts such as eastern, western and middle districts, positive effect of OFDI on the export in the three districts is also significant, but imbalanced. Positive effect of OFDI on export in middle and western districts is greater than that in the eastern district.

This article enrich the research of China's export effect of OFDI through extending the study to the regional panel level and estimating the effect respectively in China's three districts. But this paper didn't discuss the reason of the imbalanced effect between China's three districts which will be the direction for future research.

\subsection{Suggestion}

From the above analysis, China's OFDI on the one hand can explore the international market, promote the intermediate products export, on the other hand it can absorb the foreign good resources and make the products more competitive. Therefore, China can encourage the competitive districts and corporations to further explore the international markets and absorb foreign advanced technology and management experience through OFDI, and stimulate districts and corporations with comparative advantage to implement OFDI in de veloping countries along the Belt and Road to further promote the development of intermediate product exports and take advantage of low cost.

\section{References}

Bajo-Rubio, O., \& Montero-Muñoz, M. (2001). Foreign direct investment and trade: a causality analysis. Open Economies Review, 12(3), 305-323. https://doi.org/10.1023/A:1011185507169

Benwu, X. (2009). An Empirical Research on the Features of Host -country and China's Direct Investment Abroad. The Journal of Quantitative \& Technical Economics, 7, 33-46.

Brainard, S. L. (1992). A simple theory of multinational corporations and trade with a trade-off between proximity and concentration. Nber Working Papers, 87(2), 118-124.

Brainard, S. L. (1997). An empirical assessment of the proximity-concentration trade-off between multinational sales and trade. American Economic Review, 87(4), 520-544.

Chunping, Z. (2012). The Study on the Effects of China's OFDI on International Trade. The Journal of Quantitative \& Technical Economics, (6), 74-85.

Clausing, K. A. (2000). Does multinational activity displace trade? Economic Inquiry, 38(2), 190-205. https://doi.org/10.1111/j.1465-7295.2000.tb00013.x

Dunning, J. H. (1977), Trade, Location of Economic Activity and the Multinational Enterprise: A Search for an Eclectic Approach in Ohlin, B., Hesselborn and Wijkman, P. M. (eds), The International Allocation of Economic Activity, Macmillan, London, 395-418. https://doi.org/10.1007/978-1-349-03196-2_38

Eaton, J., \& Tamura, A. (1994). Bilateralism and regionalism in japanese and u.s. trade and direct foreign investment patterns. Journal of the Japanese \& International Economies, 8(4), 478-510. https://doi.org/10.1006/jjie.1994.1025

Egger, P. (2001). European exports and outward foreign direct investment: a dynamic panel data approach. Review of World Economics, 137(3), 427-449. https://doi.org/10.1007/BF02707625

Guanhong, J., \& Dianchun, J. (2014). Outward Direct Investment and Export. Economic Research Journal, 5, $160-173$.

Helpman, E. (1984). A simple theory of international trade with multinational corporations. Journal of Political Economy, 92(3), 451-471. https://doi.org/10.1086/261236

Jifeng, Z., \& Ping, H. (2013). Substitute Exports or Promote Exports?-Study on the Influence China's Outward Foreign Direct Investment on Exports. Journal of International Trade, 3, 95-103. 
Lipsey, R. E., \& Weiss, M. Y. (1981). Foreign production and exports in manufacturing industries. Review of Economics \& Statistics, 63(4), 488-494. https://doi.org/10.2307/1935843

Lipsey, R. E., \& Weiss, M. Y. (1984). Foreign production and exports of individual firms. Review of Economics \& Statistics, 66(2), 304-308. https://doi.org/10.2307/1925832

Markusen, J. R. (1984). Multinationals, multi-plant economies, and the gains from trade. Journal of International Economics, 16(3-4), 205-226. https://doi.org/10.1016/S0022-1996(84)80001-X

Markusen, J. R., \& Venables, A. J. (1998). Multinational firms and the new trade theory. Journal of International Economics, 46(2), 183-203. https://doi.org/10.1016/S0022-1996(97)00052-4

Mundell, R. A. (1957). International trade and factor mobility. American Economic Review, 47(3), 321-335.

Pfaffermayr, M. (1994). Foreign direct investment and exports: a time series approach. Applied Economics, 26(4), 337-351. http://dx.doi.org/10.1080/00036849400000080

Qiling, M., \& Jiayun, X. (2014). Does OFDI of China's Corporation Promote Innovation. The Journal of World Economy, 8, 98-125.

Shuli, W., \& Jiaojiao, X. (2014). Creation Effect or Substitution Effect: A Study on the Effect Mechanism of China's Outward Foreign Direct Investment on Import and Export. World Economy Studies, 6, 66-72, 89.

Svensson, R. (1996). Effects of overseas production on home country exports: evidence based on swedish multinationals. Review of World Economics, 132(2), 304-329. https://doi.org/10.1007/BF02707809

\section{Copyrights}

Copyright for this article is retained by the author(s), with first publication rights granted to the journal.

This is an open-access article distributed under the terms and conditions of the Creative Commons Attribution license (http://creativecommons.org/licenses/by/4.0/). 